\title{
Primeiro registro de Lepteces ornatus Rathbun (Decapoda, Brachyura, Majidae) para o Atlântico Sul
}

\author{
Gustavo Augusto S. de Melo 1, 2 \\ Thais Brandini Crivelaro ${ }^{1}$
}

\begin{abstract}
First record of Lepteces ornatus Rathbun (Decapoda, Brachyura, Majidae) for the Southwestern Atlantic. During the project GEDIP, in the coast of the State of Rio Grande do Sul, with some stations off Uruguay, a specimen female of the brachyuran crab Lepteces ornatus Rathbun, 1893 was found. Up till now this species was known only by his type material, from Arrowsmith Bank, Yukatan, Mexico. Description, material examined and distribution are done.

KEY WORDS. Uruguay, Lepteces ornatus, Brachyura, Majidae, new record, Southwestern Atlantic
\end{abstract}

Durante o projeto GEDIP (Grupo Executivo do Desenvolvimento da Indústria da Pesca), no litoral do Rio Grande do Sul, com algumas estações na costa do Uruguai, executado entre 1968 e 1972, foi coletado um exemplar fêmea de Lepteces ornatus Rathbun, 1893, pertencente à família Majidae Samouelle, 1819, cuja distribuição era conhecida somente para sua localidade-tipo, Arrowsmith Bank, Yucatan, México, sendo esta, a primeira ocorrência e registro desta espécie para o Atlântico Sul. Até esta ocorrência, apenas o material-tipo era conhecido, não havendo outras referências além do trabalho de descrição da espécie.

Esta espécie ocorre entre $180 \mathrm{~m}$ (Uruguai) e $250 \mathrm{~m}$ (Yucatan, México) de profundidade, tendo preferência por fundos de areia, mas ocorrendo, também, em corais (RATHBUN 1893, 1925).

O espécime fêmea analisado, coincide perfeitamente com a descrição original e está depositado na Coleção Carcinológica do Museu de Zoologia da Universidade de São Paulo, sob o número MZUSP-6126.

\section{Lepteces ornatus Rathbun, 1893}

Fig. 1

Lepteces ornatus Rathbun, 1893: 84, pl. VI, fig. 1; 1925: 292, pl. 244, fig. 2.

Carapaça piriforme, mais longa do que larga, ornamentada com tubérculos de dois tipos: o primeiro e mais proeminente, em forma de cogumelo, eleva-se por um disco plano, circular, granulado e de cor branca. Tubérculos deste tipo, com discos imbricados, circundam a região cardíaca e contornam a margem interna da região branquial; uma linha na extremidade metagástrica; quatro, seguindo, de cada lado, a margem póstero-lateral; dois dispostos transversalmente na região intestinal;

1) Museu de Zoologia, Universidade de São Paulo. Avenida Nazareth 481, 04263-000 São

Paulo, São Paulo, E-mail: gasmelo@usp.br, tbc@mailbr.com.br

2) Bolsista do CNPq

Revta bras. Zool. 19 (3): 777 - 779, 2002 


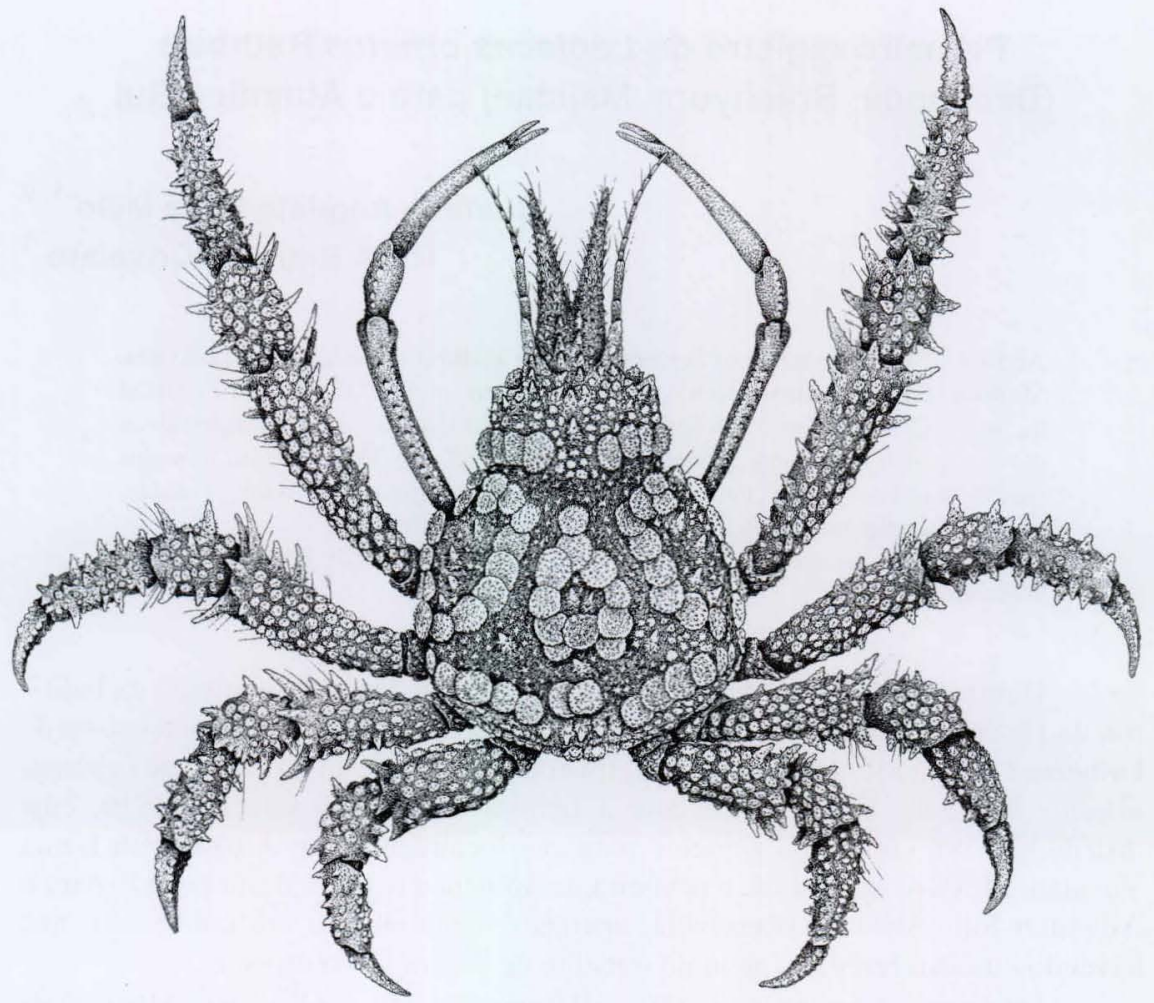

Fig. 1. Lepteces ornatus, vista dorsal (modificada de RATHBUN 1893).

linha de quatro atravessando quase transversalmente cada região hepática, avançando na região gástrica; muitos tubérculos menores, deste tipo, adicionais. Segunda variedade de tubérculos menor, levemente mais elevada do que a primeira, com extremidade arredondada, granulosa, e com algumas longas cerdas; quatro tubérculos deste tipo na região gástrica, dois dos quais na linha mediana; seis na região branquial; dois ou três na região cardíaca e três na margem posterior. Toda a superfície, entre e sob os tubérculos, repleta de grânulos estelares, que variam em tamanho. Rostro duplo, divergente, com cerdas longas, principalmente na margem interna e afilando gradativamente. Espinho pré-ocular agudo, côncavo, curvado fortemente para cima, em ângulo de cerca de $45^{\circ}$ com o rostro e com algumas longas cerdas na extremidade. Artículo basal da antena com margem externa convexa e com forte espinho dirigido para a frente, no ângulo ântero-lateral; flagelo antenal ultrapassando o rostro. Fossetas antenulares verticais; lâmina que separa as fossetas antenulares larga e com pequenos espinhos nas margens. Epístoma agudamente rebaixado medianamente. Região pterigostomial totalmente granulada. Terceiros maxilípodos com carpopodito mais longo do que o meropodito e com margens internas denteadas. Exopodito alcançando o fim do meropodito. Quelípodos fracos 
em ambos os sexos, muito mais curtos do que as patas ambulatórias; mero cilíndrico e irregular; carpo granulado; palmas lisas, afilando nos dedos, que são $1 / 5$ do comprimento da margem superior da palma. Patas ambulatórias fortes, levemente angulosas, armadas com duas fileiras longitudinais e irregulares de espinhos e tubérculos; dátilos um tanto ásperos, com extremidades córneas. Abdome das fêmeas largo e com todos os somitos livres; primeiros três somitos recobertos por pequenos grânulos espinhosos.

Material examinado. Um espécime fêmea, Projeto GEDIP, "Prof. W. Besnard" col., est. $1881,34^{\circ} 45^{\prime} \mathrm{S}, 52^{\circ} 05^{\prime} \mathrm{W}$, Uruguai, $180 \mathrm{~m}, 15 . \mathrm{VIII} .1972$ (MZUSP6126).

Distribuição geográfica. Atlântico Ocidental - México (Arrowsmith Bank, Yucatan) e Uruguai ( $\left.34^{\circ} 45^{\prime} \mathrm{S}, 52^{\circ} 05^{\prime} \mathrm{W}\right)$.

\section{REFERÊNCIAS BIBLIOGRÁFICAS}

Rathbun, M.J. 1893. Catalogue of the crabs of the family Maiidae in the U.S. National Museum. Proc.

U.S. Natn. Mus. 16 (927): 63-103.

1925. The spider crabs of América. Bull. U.S. Natn. Mus. 129: 1-593.

Recebido em 13.III.2002; aceito em 15.VIII.2002. 